Bulletin of the Natural History Museum, 2020, 13: 253-265.

Received 9 Feb 2020; Accepted 2 Aug 2020.

doi:10.5937/bnhmb2013253U

UDC: $598.161 .41(497.11)$

Original scientific paper

\title{
DISTRIBUTION OF THE SLOW WORM (ANGUIS FRAGILIS COMPLEX) WITH POSSIBLE SPECIES DELIMITATION IN SERBIA
}

\footnotetext{
ALEKSANDAR UROŠEVIĆ ${ }^{1 *}$, LJILJANA TOMOVIĆ ${ }^{2}$, JELKA CRNOBRNJAISAILOVIĆ ${ }^{1,3}$, IMRE KRIZMANIĆ ${ }^{2}$, RASTKO AJTIĆ ${ }^{4}$, NENAD LABUS ${ }^{5}$, MARKO ANĐELKOVIĆ ${ }^{1}$, SONJA NiKOLIĆ ${ }^{2}$, DANKO JOVIĆ ${ }^{6}$, MILIVOJ KRSTIĆ ${ }^{7}$, MARKO MARIČIĆ ${ }^{2}$, ALEKSANDAR SIMOVIĆ ${ }^{7}$, ANA PAUNOVIĆ ${ }^{8}$, VLADIMIR ŽIKIĆ JELENA ĆOROVIĆ ${ }^{1}$, TIJANA VUČIĆ ${ }^{2}$, TIJANA ČUBRIĆ ${ }^{3}$, GEORG DŽUKIĆ ${ }^{1}$

${ }^{1}$ University of Belgrade, Institute for Biological Research "Siniša Stanković" National Institute of Republic of Serbia, Bulevar Despota Stefana 142, 11000 Belgrade, Serbia, e-mail: aurosevic@ibiss.bg.ac.rs

${ }^{2}$ University of Belgrade, Faculty of Biology, Institute of Zoology, Studentski trg 16, 11000 Belgrade, Serbia

${ }^{3}$ University of Niš, Faculty of Sciences and Mathematics, Department of Biology and Ecology, Višegradska 33, 18000 Niš, Serbia

${ }^{4}$ Institute for Nature Conservation of Serbia, Dr Ivana Ribara 91, 11070 Belgrade, Serbia

${ }^{5}$ University of Priština, Faculty of Science and Mathematics, Biology Department, Lole Ribara 29, 38220 Kosovska Mitrovica, Serbia

${ }^{6}$ Institute for Nature Conservation of Serbia, Office in Niš. Vožda Karađorđa 14, 18000 Niš, Serbia

${ }^{7}$ Serbian Herpetological Society "Milutin Radovanović". Despota Stefana Blvd. 142, 11000 Belgrade, Serbia

${ }^{8}$ Natural History Museum in Belgrade. Njegoševa 51, 11000 Belgrade, Serbia
}

In this study, we present an updated distribution data of Anguis fragilis complex species in Serbia. The dataset consists of literature and Internet records, coupled with previously unpublished distribution data gathered in the field. Of the 
two species of the complex, Anguis fragilis is present in the western and southern parts of the country while Anguis colchica is present in the northeastern and eastern parts of the country. There is an absence of both species in the northernmost parts of the country, due to the lack of adequate habitat. The field records tend to be more abundant in the Mountain-valley altitudinal region, and scarcer and more scattered in the Peripannonian and Pannonian altitudinal regions, which can partly be attributed to the sampling bias. The location and width of the contact zone are still poorly known. It's hypothesized to follow the Velika Morava river valley to the south and then the boundary between the Carpathian-Balkan and Rhodope mountain ranges in the southeast, but the hybrid zone could be situated more to the west. There is a certain discrepancy, in the literature, between the contact zone proposed by morphological data, and the one proposed by molecular sampling. That stresses the need for thorough sampling in the region and further analyses. Finally, since the taxonomic split between the cryptic slow worm taxa was not yet recognized in our national nomenclature, this paper also presents the official Serbian names for the two species. The species Anguis fragilis will keep the standard Serbian name "Slepić", while for the species Anguis colchica we propose the name "Istočni slepić".

Keywords: Distribution, Anguis, zoogeography, hybrid zone

\section{INTRODUCTION}

The geographical distribution of various taxa in many parts of the world is still incompletely known, and correct georeferencing of locality data is of utmost importance for biogeographic studies (Meiri 2018). Employment of new methods of molecular biology, use of integrative systematics (de Queiroz 2007, Pante et al. 2015), taxonomic updates and discoveries of hybrid zones and cryptic taxa often reveal unexpected species distribution patterns (Delić et al. 2017).

The Anguis fragilis species complex is among such examples. Recent studies confirmed that what was once considered a polytypic species is, in fact, a group of five cryptic species with very complex evolutionary histories (Gvoždík et al. 2010, 2013, Jablonski et al. 2016, 2017). These species can partially be distinguished morphologically, but with a great overlap in characters (Arnold \& Ovenden 2002, Speybroeck et al. 2016) and "intermediate" phenotypes are often found in contact zones (Szabó \& Vörös 2014, Kaczmarek \& Skórzewski 2015). According to the current literature (Gvoždík et al. 2013, Jablonski et al. 2016), Serbia should be inhabited by two species of the complex, Anguis fragilis Linnaeus, 1758 in most of its territory and $A$. colchica Nordmann, 1840 in eastern parts.

The distribution of Anguis fragilis complex in the Western Balkans (former Yugoslavia) was not particularly thoroughly studied during most of 
the XX century and, consequently, its exact distribution in Serbia is still poorly known, and with large gaps. Radovanović (1951) mentioned it as ubiquitous and sporadically very abundant. Brelih and Džukić (1974) listed both taxa (at that time regarded as subspecies) in the former Yugoslavia, with the fragilis taxon being present in the western parts of the country and the mountains in the east, while colchica was frequent in the eastern parts of the country, with an unclear boundary between the two. The more detailed study, conducted on numerous morphological and meristic characters (Džukić 1987), determined that $A$. fragilis complex is absent from parts of northern Serbia (most of the Vojvodina province); the nominotypical subspecies is present in the western parts of Serbia, most of Kosovo and Metohija and in highlands in the east, while the eastern subspecies is found in central and eastern parts of Serbia. In places where the two subspecies came into contact, the animals with "intermediate" phenotype and populations consisted of individuals with characters of both subspecies were found. The hypothesized hybrid zone is wide in the lowland and narrow in the highland parts of the country (Džukić 1987).

The latest confirmed and potential distribution range of Anguis fragilis complex in Serbia was published in 2014 (Tomović et al. 2014). The most recent molecular studies (Jablonski et al. 2016) revealed that A. colchica is more restricted in the eastern and north-eastern parts of Serbia than assumed by Džukić (1987), being essentially related to the Carpathians and the Balkan mountains, while $A$. fragilis follows the Dinaric massif and the Rhodope mountains. Although haplotypes of both species were found in two locations, namely along the Velika Morava River and southwestern slopes of the Stara Planina Mt. (Jablonski et al. 2016), the exact location and width of the contact zone are still insufficiently known, mostly due to the lack of DNA samples from central and eastern parts of Serbia.

The present study aimed to compile the available records of Anguis fragilis complex in Serbia and provide an update of the known distribution georeferenced at the $10 \times 10 \mathrm{~km}$ standardized UTM grid (Universal Transverse Mercator). The existing georeferenced data is mapped along with the hypothesized hybrid/contact zone to visualize the priority spots for future faunistic research and DNA sampling.

In this paper, we also proposed the official Serbian nomenclature for these two taxa.

\section{MATERIAL AND METHODS}

We compiled the data from literature records (104 findings), with additional 61 from the Herpetological Collection of the Institute for the 
Biological Research "Siniša Stanković" - University of Belgrade, verifiable online records from field herpetology and biodiversity websites (63), and previously unpublished data (321) collected by the co-authors and collaborators mentioned in the Acknowledgements (Figure 1). All field data presented in this study are listed by locality names in Appendix 1. The complete list of literature records, including the Herpetological Collection, is given in Appendix 2. When using data from the Internet, namely websites Balcanica (Balej \& Jablonski 2015), iNaturalist (iNaturalist.org 2020a, 2020b), and Biologer (Maričić \& Golubović 2020), we complied with terms and conditions of websites and asked site administrators and contributors for permissions to cite their entries. The complete website data with individual citations and authorship for each entry are provided in Appendix 3.

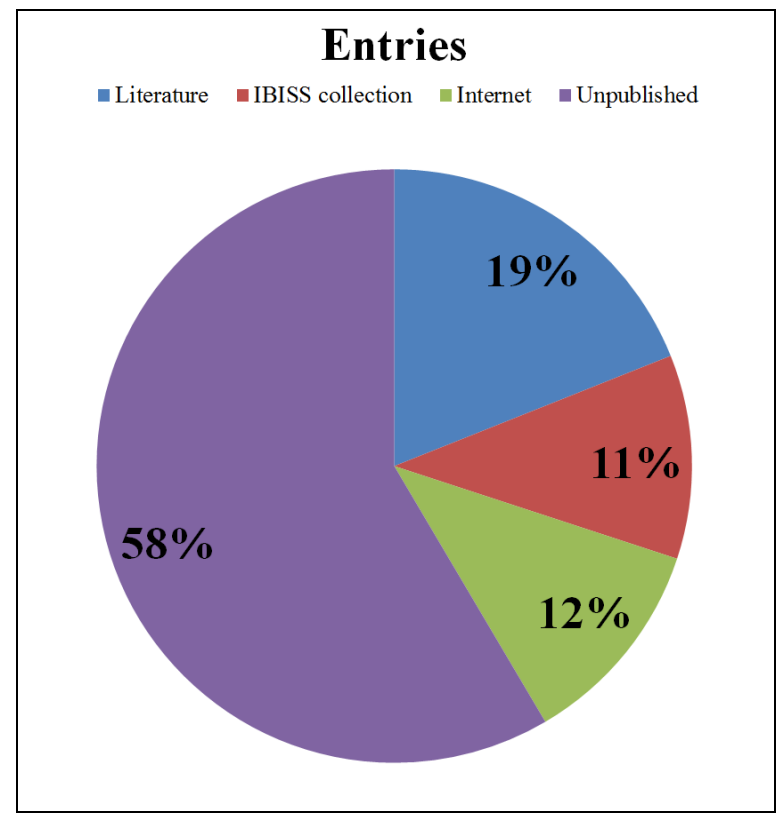

Fig. 1. - Percentage of entries from each source.

All collected records were mapped on the $10 \times 10 \mathrm{~km}$ UTM geographic coordinate grid system. The hypothetical boundary between the A. fragilis and A. colchica was inferred from the literature, based on the phylogeographic studies of $A$. fragilis complex from the Balkans and Central Europe (Jablonski et al. 2016, 2017). Biogeographic regions of Serbia we used in this paper were defined by Marković (1970) and Stevanović (1992): Bačka

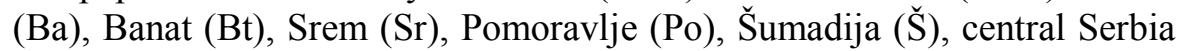
(C), northeastern Serbia (NE), eastern Serbia (E), northwestern Serbia (NW), southeastern Serbia (SE), western Serbia (W), southwestern Serbia (SW), southern Serbia (S), Kosovo (K), and Metohija (M) (Figure 2). 


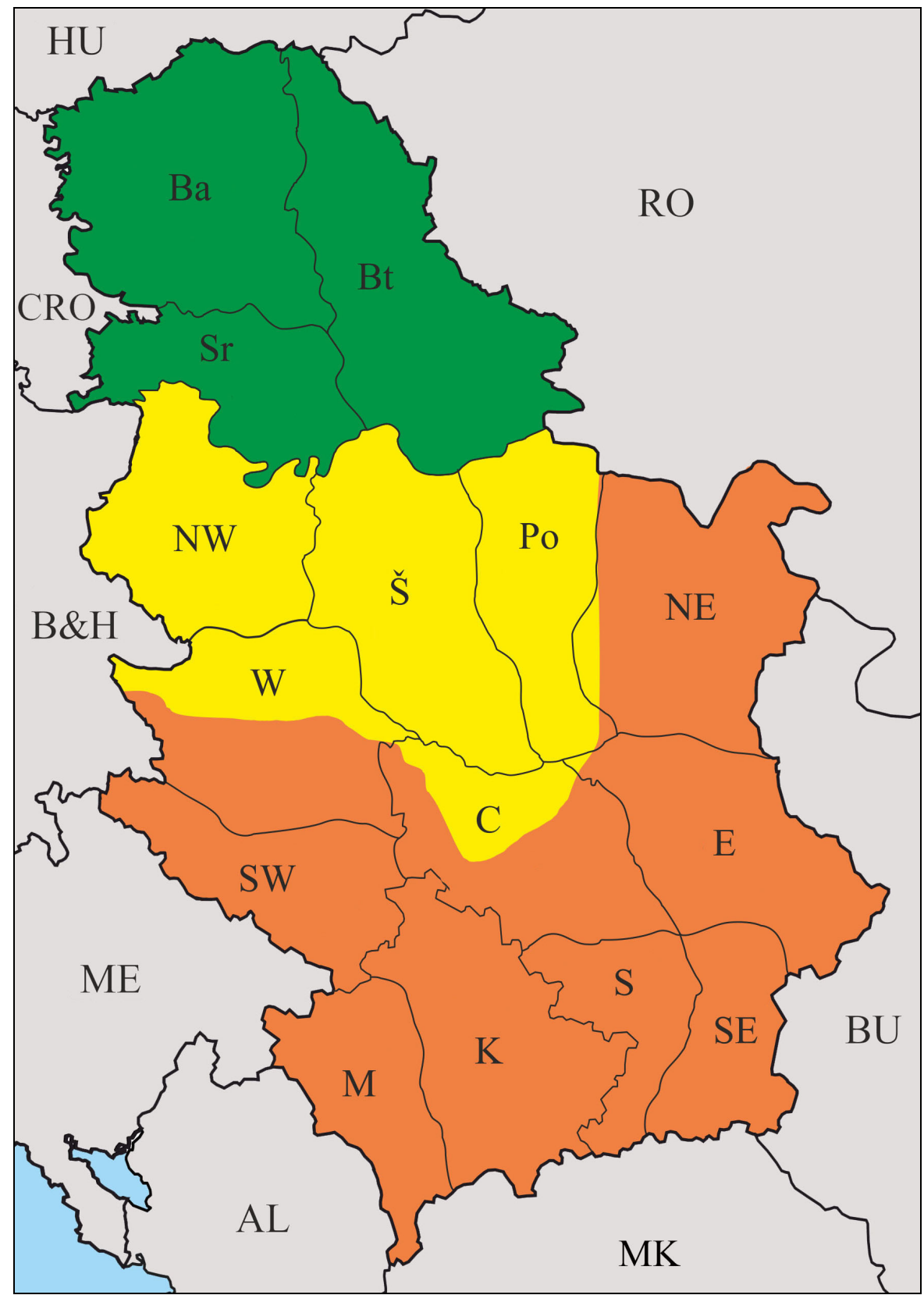

Fig. 2. - Altitudinal and biogeographic regions of Serbia. Altitudinal zones: green - Pannonian, yellow - Peripannonian, orange - mountain-valley. Biogeographic regions: Ba - Bačka, Bt - Banat, Sr - Srem, Po - Pomoravlje, Š - Šumadija, C central Serbia, NE - northeastern Serbia, NW - northwestern Serbia, E - eastern Serbia, W - western Serbia, SE - southeastern Serbia, SW - southwestern Serbia, $\mathrm{S}$ - southern Serbia, K - Kosovo, and M - Metohija. 


\section{RESULTS}

Of the compiled distribution data of the Anguis fragilis complex, all those previously published represent only $40.9 \%$ while the unpublished field data amounted to $59.1 \%$ of the records in this paper. Despite numerous new UTM records, distribution of Slow worms in Serbia is still patchy (Figure 3). It could result from a lack of systematic effort in data gathering in most parts of the country. Also, being rather secretive, semifossorial, Slow worms often remain unnoticed and incidental observations are relatively rare. The Slow worm is present at all altitudes and in all biogeographic regions of Serbia, but distribution gaps are evident in some areas. Apparently, it is uncommon in the Peripannonian and quite scarce in the Pannonian parts of Serbia, compared to the Mountain-valley portion. The largest distribution gaps still exist in central and northern Banat, central parts of Srem, the most of Bačka and a large part of Pomoravlje regions. On the other hand, large clusters of findings relate to montane areas.

\section{DISCUSSION}

The combined analysis of records from the most recent distribution map of A. fragilis complex in Serbia (Tomović et al. 2014) and phylogeographic study of Jablonski et al. (2016) provided precise, although scattered, locality data for Serbia, especially fragmentary for A. colchica. However, the latter was a large study covering the entire Balkans so Serbia was not in focus.

The inferred absence of Slow worms from the northernmost parts of the country (northern and central Banat and most of Bačka) is likely real, i.e. not a result of sampling bias; recent field excursions also did not provide records from these areas. It could be related to the inhospitality of the given lowland terrain that has, to a great extent, been converted into agricultural land (i.e. cultivated steppe) and, thus, lacks the natural Slow worm habitats - usually damp, densely vegetated places such as forests, meadows, scrubland, heath, gardens, parks and fields with some bushy cover (Radovanović 1951, Džukić 1987, Arnold \& Ovenden 2002, Speybroeck et al. 2016).

In the rest of Serbia, especially in large parts of the Srem and Pomoravlje regions, the absence of records most likely resulted from inadequate sampling; however, in these regions, fairly large areas are also cultivated and do not provide suitable habitats for Slow worm. 


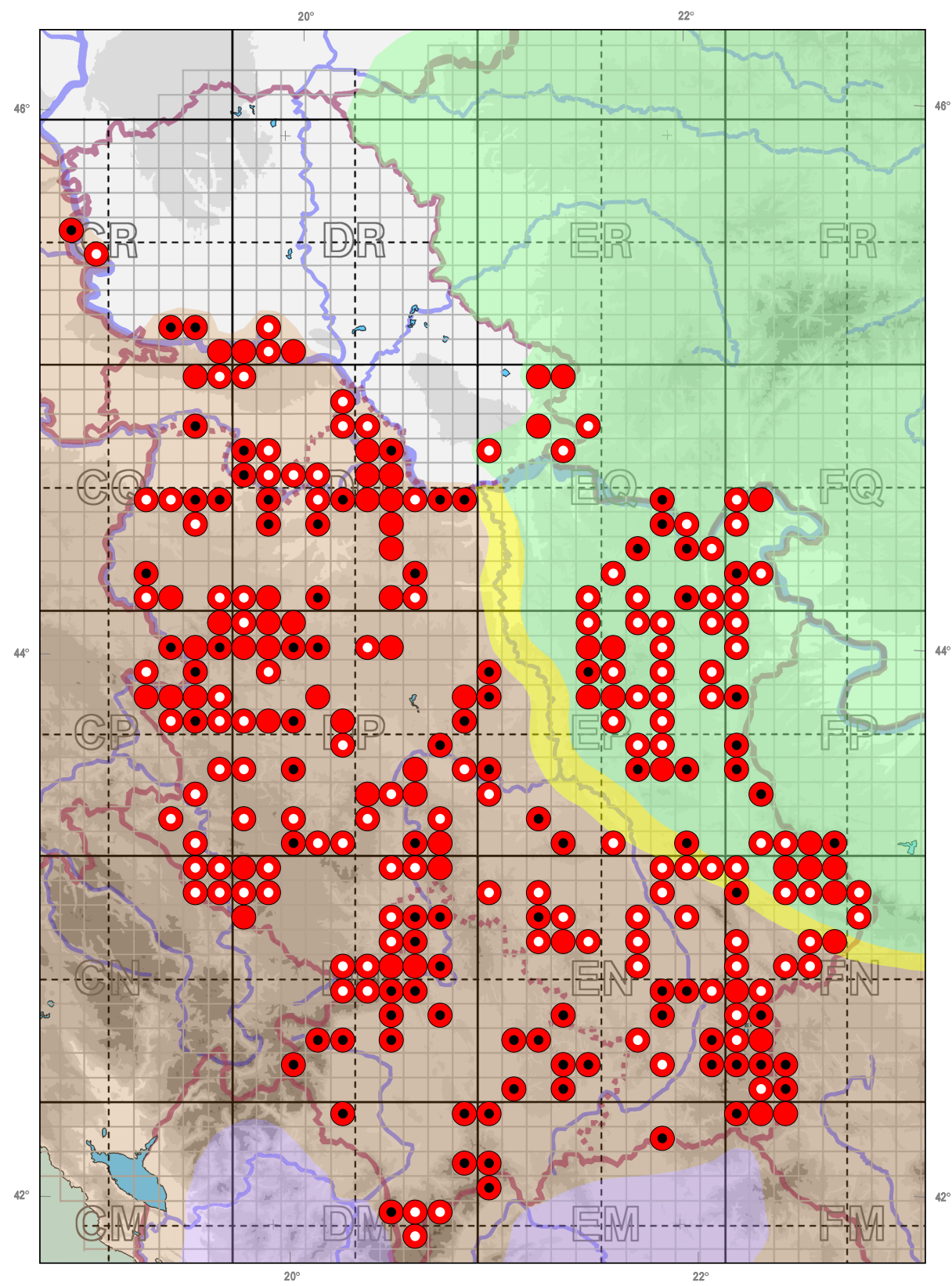

Fig. 3. - Records of Anguis fragilis complex from Serbia. Concentric red and white circles - new records, concentric red and black circles - literature and Internet records, full red circles - literature records confirmed by new findings. The boundaries of three species of Anguis are given according to the hypothetical ranges by Jablonski et al. (2016): brown shading - Anguis fragilis, green shading - Anguis colchica, violet shading - Anguis graeca, yellow shading - contact zone. 
The real conundrum regarding Slow worm distribution in Serbia is the exact location of the contact zone between A. fragilis and A. colchica. The species $A$. colchica is, according to the boundary proposed by Jablonski et al. (2016), restricted to southern Banat and northeastern Serbia, while Pomoravlje and Eastern Serbia harbour both species and their range boundaries (Figures 2 and 3). It should be noted that, according to morphological analyses by Džukić (1987), the contact zone could also extend into Šumadija and Central Serbia regions.

The contact zone proposed by Džukić (1987) was based on the presence of individuals with "intermediate" morphological and meristic characters. However, it was noted that the animals in this zone morphologically resemble more $A$. fragilis than $A$. colchica (Džukić 1987). This contact zone was strongly indented, following the terrain. It was wide in the lowlands and highland plateaus and narrow in the mountains. It distinguished the putative $A$. fragilis as a montane taxon, also present as extralimital in the mountains in the eastern part of the country, and putative A. colchica as primarily lowland taxon. Phylogeographic studies (Jablonski et al. 2016, 2017) provided somewhat different picture, where the distribution of $A$. colchica is largely restricted to the Carpathian and Balkan massifs, and Velika Morava and Danube rivers were proposed as eastern and northern borders of $A$. fragilis in Serbia. However, haplotypes of the two species were found in several areas, and the contact/hybrid zones could be anywhere in these corridors. For simplicity, we interpolated the hypothetical distribution of the A. fragilis complex species from the Jablonski et al. (2016) paper onto our distribution map (Figure 3) to identify areas that should be priorities for DNA sampling to correctly assess the location and width of the contact zone. In lowlands, hybridization between the two target taxa can happen along a very wide front (Szabó \& Vörös 2014, Kaczmarek \& Skórzewski 2015). Already Džukić (1987) implied this possibility through the presence of Slow worms with "intermediate" phenotypes. Thus, the western border of the contact zone could respond to the one described by Džukić (1987). The said contact zone would be roughly situated in the Sumadija region while, moving to the southeast, it would narrow increasingly and reduce to the gorges and passes between the Balkan and Rhodope mountain ranges.

There is also a possibility that the third species, Anguis graeca Bedriaga, 1881 is present in Serbia, although its hypothesized range borders are in North Macedonia and Albania, south of the Serbian border (Jablonski et al. 2016) (Figure 3). Therefore, Slow worms along the southern Serbian border should also be sampled for DNA to check for the presence of $A$. graeca or its contact zone with A. fragilis. 
The presence of marginal populations and a contact zone (Džukić \& Kalezić 2004) of two slow worm species makes the territory of Serbia important concerning the evolutionary history of Anguis species (Jablonski et al. 2016, 2017). The legal status of Slow worm in Serbia could change as it is currently considered a single species and not protected by law. Consequently, the national conservation status could be reconsidered and provided for A. fragilis and A. colchica separately.

\section{CONCLUSIONS}

Although new distribution data greatly expanded our knowledge on the distribution of the slow worms complex in Serbia, many questions remain open. There are still distribution gaps in the proposed range that could be related to the lack of sampling or genuine absence from agricultural habitats. Even more important issue is the location and width of the contact zone of A. fragilis and A. colchica since there is a certain discrepancy between the old maps based on morphological data and the new ones revealed by molecular studies. Intensified DNA sampling in the hypothetical contact zone (and in the southern border areas for the possible presence of $A$. graeca) should be conducted soon to precisely define the exact distributions of the slow worm species in Serbia and the location and width of their contact zone. Considering the official national nomenclature, we propose that the nominotypic species, Anguis fragilis, should keep the standard Serbian name "Slepić", while for the species Anguis colchica we propose Serbian name "Istočni slepić", following the species distribution in Serbia and Europe in general.

\section{Acknowledgements}

This research was partly financed by the Ministry of Education, Science and Technological Development of Republic of Serbia - Grants No. 45103-68/2020-14/200007 (A.U., J.C.I., M.A J.Ć., G.Dž); 451-03-68/2020-14/ 200178 (Lj.T., I.K., S.N., M.M., T.V.); 173025 (J.C.I., J.Ć., T.Č) and 173043 (A.U., Lj.T., M.A., S.N., T.V., G.Dž.); National Park "Kopaonik" project Monitoring vodozemaca i gmizavaca na prostoru Nacionalnog parka Kopaonik 2 (grants nos. 1124/2018, 1895/2019); Rufford Small Grants Foundation (grants no. 20507-B); Ministry of Agriculture and Environmental Protection of the Republic of Serbia (grant no. 401-0000243/2014-08, the "DNA project") and Data collecting for Natura 2000 network in Republic of Serbia (grant no. JNOP 02/ 2019). We gratefully acknowledge A. Golubović, A. Ivanović, A. Miletić, A. Mitić, B. Kostić, B. Ordić, B. Preljević, D. Bogdanović, D. Milenković, D. Petrović, D. 
Todorović, E. Kljajić, G. Tomović, I. Babić, I. Božović, I. Milutinović, J. Pavlović, J. Purger, L. Đurđević, L. Rubinjoni, M. Ajduković, M. Cvijanović, M. Kalezić, M. Mirč, M. Niketić, M. Plećaš, M. Vasić, N. Preradović, N. Pupe, N. Radivojević, N. Tomašević-Kolarov, P. Bosnić, P. Cakić, S. Antić, S. Petković, S. Radovanović, S. Sij, T. Vukov, V. Cvetković, V. Kalafatić, V. Milojević, Z. Cuparić, Z. Dunđerski and Z. Marinković for sharing their field data and/or help in the field. Some field data were provided by the members of the Serbian Herpetological Society "Milutin Radovanović", BID "Josif Pančić", NIDSBE "Josif Pančić" and the research station "Petnica".

\section{REFERENCES}

Arnold, E. N., Ovenden, D. (2002): A Field Guide to the Reptiles and Amphibians of Britain and Europe. - Harper Collins Publishers, London.

Balej, P., Jablonski, D. (2006-2019): Balcanica.info. [http://www.balcanica.cz/]

Brelih, S., Džukić, G. (1974): Catalogus Faunae Jugoslaviae IV/2 Reptilia. Slovenian Academy of Sciences and Arts, Ljubljana.

Crnobrnja-Isailović, J., Jelić, I., Stanisavljević, B., Ćosić, N. (2012): Vodozemci i gmizavci Beograda: 117. - Endemit, Beograd.

Delić, T., Trontelj, P., Rendoš, M., Fišer, C. (2017): The importance of naming cryptic species and the conservation of endemic subterranean amphipods. Scientific Reports 7: 3391.

De Queiroz, K. (2007): Species concepts and species delimitation. - Systematic Biology 56(6): 879-886.

Džukić, G. (1972): Herpetološka zbirka Prirodnjačkog muzeja u Beogradu. Glasnik Prirodnjačkog muzeja u Beogradu Serija B 27: 165-180.

Džukić, G. (1987): Taxonomic and biogeographic characteristics of the slow-worm (Anguis fragilis Linnaeus 1758) in Yugoslavia and on the Balkan Peninsula. Scopolia 12: 1-47.

Džukić, G., Kalezić, M. (2004): The biodiversity of amphibians and reptiles in the Balkan Peninsula. In: Griffiths, H., Krystufek, B., Reed, J. M. (ed.): Balkan Biodiversity. Pattern and Process in the European Hotspot: 1-26. - Springer, Dordrecht.

Džukić, G., Tomović, Lj., Anđelković, M., Urošević, A., Nikolić, S., Kalezić, M. (2017): The herpetological collection of the Institute for Biological Research "Siniša Stanković", University of Belgrade. - Bulletin of the Natural History Museum, Belgrade 10: 57-104.

Gvoždík, V., Jandzik, D., Lymberakis, P., Jablonski, D., Moravec, J. (2010): Slow worm, Anguis fragilis (Reptilia: Anguidae) as a species complex: Genetic structure reveals deep divergences. - Molecular Phylogenetics and Evolution 55: $460-472$. 
Gvoždík, V., Benkovský, N., Crottini, A., Bellati, A., Moravec, J., Romano, A., Sacchi, R., Jandzik, D. (2013): An ancient lineage of slow worms, genus Anguis (Squamata: Anguidae), survived in the Italian Peninsula. - Molecular Phylogenetics and Evolution 69: 1077-1092.

iNaturalist.org (2020a): Anguis colchica. [GBIF.org (22 September 2020) GBIF Occurrence Download https://doi.org/10.15468/d1.pjm3js

iNaturalist.org (2020b): Anguis fragilis. [GBIF.org (22 September 2020) GBIF Occurrence Download https://doi.org/10.15468/dl.ajmn9t]

Jablonski, D., Jandzik, D., Mikulíček, P., Džukić, G., Ljubisavljević, K., Tzankov, N., Jelić, D., Thanou, E., Moravec, J., Gvoždík, V. (2016): Contrasting evolutionary histories of the legless lizards slow worms (Anguis) shaped by the topography of the Balkan Peninsula. - BMC Evolutionary Biology 16: 99.

Jablonski, D., Najbar, B., Grochowalska, R., Gvoždík, V., Strzała, T. (2017): Phylogeography and postglacial colonization of Central Europe by Anguis fragilis and Anguis colchica. - Amphibia-Reptilia 38: 562-569.

Kaczmarek, P., Skórzewski, G. (2015): Do Anguis fragilis L. and Anguis colchica (Nordman, 1840) hybridize in the south central part of Poland? Morphological signs of introgression between two species of slow worm and range of Anguis colchica in Poland - preliminary results. In: Borczyk B., Ogielska M., Kolenda K., Skawiński T. (eds): Programme \& Abstracts XVIII European Congress of Herpetology: 139. - University of Wroclaw, Societas Europaea Herpetologica, Wroclaw. (Abstract)

Maričić, M., Golubović, A. (2020): Anguis fragilis. In: Popović, M., Golubović, A., Živanović, N. (eds): Biologer.org. [https://biologer.org (18 July 2020)]

Marković, J. Đ. (1970): Geografske oblasti Socijalističke Federativne Republike Jugoslavije. - Zavod za udžbenike i nastavna sredstva Srbije, Beograd.

Meiri, S. (2018): The smartphone fallacy - when spatial data are reported at spatial scales finer than the organisms themselves. - Frontiers in Biogeography 10.1: e38642.

Münch, H. (1997): Zoologische Beobachtungen auf dem Balkan von 1941 bis 1945. - Rudolstädter Naturhistorische Schriften Supplement 2: 99.

Pante, E., Schoelinck, C., Puillandre, N. (2015): From integrative taxonomy to species description: one step beyond. - Systematic Biology 64(1): 152-160.

Radovanović, M. (1951): Vodozemci i gmizavci naše zemlje. - Naučna knjiga, Beograd.

Szabó, K., Vörös, J. (2014): Distribution and hybridization of Anguis fragilis and A. colchica in Hungary. - Amphibia-Reptilia 35: 135-140.

Speybroeck, J., Beukema, W., Bok, B., Van Der Voort, J. (2016): Field guide to the amphibians and reptiles of Britain and Europe. - Bloomsbury Publishing, London \& New York.

Sterijovski, B. (2014): Systematic survey of amphibian and reptile fauna in the Bosilegrad region of southern Serbia. - Biologia Serbica 36: 65-68.

Stevanović, V. (1992): Floristička podela teritorije Srbije sa pregledom viših horiona i odgovarajućih flornih elemenata. In: Sarić, M. (ed.): Flora of Serbia 1 Srpska akademija nauka i umetnosti, Beograd. 
Tadijan, Z., Mikeš, M. (1984): Herpetološka osmatranja na Fruškoj Gori. - Zbornik studentskih radova, Institut za biologiju PMF: 41-50.

Tomović, Lj., Ajtić, R., Ljubisavljević, K., Urošević, A., Jović, D., Krizmanić, I., Labus, N., Đorđević, S., Kalezić, M. L., Vukov, T., Džukić, G. (2014): Reptiles in Serbia- Distribution and Diversity Patterns. - Bulletin of the Natural History Museum 7: 129-158.

Tomović, Lj., Timotijević, M., Ajtić, R., Krizmanić, I., Labus, N. (2018): Contribution to the herpetofauna of Serbia - Distribution of Reptiles in Kosovo and Metohija province. - University Thought 8: 1-6 + Appendix 1-2 (7-25).

Urošević, A. (2018): Gmizavci smederevskog kraja - distribucija i biogeografska pripadnost: - Smederevski zbornik 6: 11-34.

\section{SUPPORTING INFORMATION}

\section{Online Appendices:}

Appendix 1. - Unpublished records.

Appendix 2. - Previously published records.

Appendix 3.- Online records.

\section{ДИСТРИБУЦИЈА СЛЕПИЋА (ANGUIS FRAGILIS COMPLEX) У СРБИЈИ, СА МОГУЋИМ РАЗГРАНИЧЕњЕМ ВРСТА}

\section{Р Е 3 И М Е}

АЛЕКСАНДАР УРОШЕВИЋ, ЉИЉАНА ТОМОВИЋ, ЈЕЛКА ЦРНОБРЬАИСАИЛОВИЋ, ИМРЕ КРИЗМАНИЋ, РАСТКО АЈТИЋ, НЕНАД ЛАБУС, МАРКО АНЪЕЛКОВИЋ, СОЊА НИКОЛИЋ, ДАНКО ЈОВИЋ, МИЛИВОЈ КРСТИЋ, МАРКО МАРИЧИЋ, АЛЕКСАНДАР СИМОВИЋ, АНА ПАУНОВИЋ, ВЛАДИМИР ЖИКИЋ, ЈЕЛЕНА ЋОРОВИЋ, ТИЈАНА ВУЧИЋ, ТИЈАНА ЧУБРИЋ, ГЕОРГ ЏУКИЋ

У овом раду, приказујемо ажуриране податке о дистрибуцији комплекса врста слепића (Anguis fragilis complex) у Србији. Подаци се састоје из налаза објављених у литератури или на Интернету, заједно са претходно необјављеним дистрибуционим подацима сакупљеним на терену. Од две врсте комплекса присутне у Србији, Anguis fragilis је 
распрострањен у западним и јужним крајевима наше земље док је Anguis colchica присутан у североисточним и источним крајевима. У најсевернијим деловима наше земље констатовано је одсуство обе врсте, због недостатка одговарајућег станишта. Налази су бројнији у планинско-котлинском региону и ређи и раштрканији у перипанонском и панонском региону, што се делимично може објаснити несистематским узорковањем. Локација и ширина контактне зоне две врсте слепића у Србији је још увек недовољно позната. Претпоставља се да се пружа дуж долине Велике Мораве ка југу а затим прати границу између Родопског и Карпатско-Балканског планинског масива ка југо-истоку, али постоје индиције да се хибридна зона налази и западније. Постоји извесно неслагање, у литератури, између контактне зоне предложене на основу морфолошких анализа и оне предложене на основу молекуларних анализа. Ово указује на потребу за опсежнијим узорковањем и даљим анализама. Коначно, пошто раздвајање две криптичке врсте слепића до сада није препознато у нашој номенклатури, у овом раду предлажемо званичне српске називе за наведене врсте. Врста Anguis fragilis ће задржати стандардно српско име „Слепић“, док за врсту Anguis colchica предлажемо име „Источни слепић“. 